\title{
Initiatives and Challenges of Agricultural Crop Sector in East Coast Economic Region (ECER) Development Projects in Malaysia
}

\author{
Md. Mahmudul Alam* \\ PhD Student \\ Institute for Environment and Development (LESTARI) \\ National University of Malaysia (UKM), Malaysia \\ E-mail: rony000@gmail.com \\ Golam Morshed \\ PhD Student \\ Institute for Environment and Development (LESTARI) \\ National University of Malaysia (UKM) \\ 43600, Bangi, Selangor, Malaysia \\ Email: gmorshed80@yahoo.com \\ Chamhuri Siwar \\ Emeritus Professor \\ Institute for Environment and Development (LESTARI) \\ National University of Malaysia \\ 43600 UKM Bangi, Selangor Darul Ehsan, Malaysia \\ E-mail: csiwar@ukm.my \\ Md. Wahid Murad \\ Lecturer \\ Business School, Faculty of the Professions \\ The University of Adelaide, Adelaide \\ South Australia, Australia \\ E-mail: wahid.murad@adelaide.edu.au \\ * Corresponding author

\section{Citation Reference:}

Alam, M.M., Morshed, G., Siwar, C., Murad, M.W. 2012. Initiatives and Challenges of Agricultural Crop Sector in ECER Development Projects in Malaysia, AmericanEurasian Journal of Agricultural \& Environmental Sciences, Vol. 12(7), pp. 922-931. [Online Link]

This is a pre-publication copy.

The published article is copyrighted by the publisher of the journal. 


\title{
Initiatives and Challenges of Agricultural Crop Sector in East Coast Economic Region (ECER) Development Projects in Malaysia
}

\begin{abstract}
The share of agriculture to GDP is continuously declining in Malaysia, but agricultural sector is very crucial to ensure food security, employment generation, socioeconomic improvement, economic growth, poverty reduction, and overall achievement of vision 2020. The East Coast Economic Region (ECER) represents $34 \%$ of total national agricultural area, which has a good potentiality to improve productivity and reduce high poverty intensity in this area. Realizing the importance, Malaysian government has taken a large development project in the ECER region in 2006, but much is not known about the project due to limited number of study and unavailability of official performance report of the project. Hence this study is an attempt to explore one of the niche areas, which is agricultural crops sector. The major initiatives of agricultural crops sector include establishing three agro valleys as major vegetable and short-term crop growing areas. These involve organized modern farming methods in a sustainable manner to improve efficiency and productivity of agricultural production of paddy, vegetables, and fruits. The prospects of the project are also very much anticipative, because the size of domestic market has grown in recent years. But there are lots of challenges to meet the target of the project. Institutional supports, physical infrastructural supports like transportations, irrigations, and preservation facilities are not adequate in this area. To meet the target and to ensure the success of the projects, some more initiatives for improvements and proper management are also necessary. These include, for example, farmer's cooperative or institutional involvement for marketing the crops, financial supports and subsidies, cooperation among agents and departments, training to avoid environment degradations, and adaptation techniques to cope with adverse effects of climatic changes, etc. It is expected that the relevant government authority and agencies, especially the ECER project authority, will be highly benefited from the findings of the study.
\end{abstract}

Key words: ECER, Agropolitan, Agriculture, Rural development, Malaysia

\section{Introduction}

In the path of economic development from agriculture to industrial movement, the agricultural sector of Malaysia has been declining with its share of GDP since 1975. In 1970, the contribution of agriculture to GDP was $30.8 \%$ which is the highest among all sectoral contributions. The contribution of the agriculture to the GDP accounted $22.7 \%$ in 1975 , $22.9 \%$ in 1980 and $20.8 \%$ in 1985 , but it was still the major contributor to the country's GDP. In 1990, agriculture became the second largest sector contributing $18.7 \%$ to the national GDP. In 1995, the contribution of agriculture to the national GDP further declined to $13.6 \%$, but it remained as the second largest sector in the economy. The contribution of the sector continued to decline to $8.9 \%$ in 2000 and then $8.2 \%$ in 2005 .

The usage of land by Malaysia's agriculture also continues to decrease due to the country's rapid economic development, which occupies more agricultural land mainly for housing, business, and industrial purposes. Since 1960 until 2005, the land use for industrial crops is increasing while it is decreasing for food crops means the major part of agricultural land is being used for growing industrial crops and that importance of growing food crops continues to decrease. In 1960, for example, land use for food crops accounted for $31.5 \%$ of 
the total agricultural land in Malaysia while it has decreased to $16.3 \%$ in 2005. Among the industrial crops, palm oil sector accounted for the largest share of the total land utilization in the country. Agricultural land use by the palm oil sector has significantly increased over the last five decades with only $2.1 \%$ in 1960 to $63.4 \%$ in 2005 . This just reveals the facts that palm oil production has been getting more importance and contributing significantly to the national economy.

In Malaysia, there is no specific policy on food security, but it has been embedded into the theme of self-sufficiency level that referred to paddy or rice sector (Arshad, Shamsudin \& Saleh 1999). Since rice is the main staple food in Malaysia, self-sufficiency level has been focused on paddy and rice production. To ensure food security in Malaysia, however, government follows two procedures, such as establishing self-sufficiency level and maintaining rice stocks both domestically and internationally. Malaysia has had never met food self-sufficiency level. About $10 \%$ to $35 \%$ of total required rice imported from neighboring countries, such as Thailand, Vietnam, Myanmar, India, and Pakistan. But, overall the agriculture sector in Malaysia has achieved positive development during the Eight Malaysia Plan. The Ninth Malaysia Plan also focused on the agriculture to ensure the development of the sector to serve as the third engine of economic growth. Malaysian government has allocated RM6 billion budget in 2010 for agriculture sector. The Tenth Malaysia Plan (2011-2015) emphasized on the high valued agriculture activities such that the contribution to GDP increases to $2 \%$ by 2015 . During the period of $10^{\text {th }}$ Malaysian Plan no new areas will be developed for paddy cultivation and local production of rice will be set to fulfill a $70 \%$ level of self-sufficiency.

Upon realizing the importance of agriculture and to achieve the target of national plan, Malaysia has taken National Agricultural Policy. To achieve the target of food production and ensuring sustainable agriculture in Malaysia, the Second National Agricultural Policy (1992-1997) was revised and the Third National Agricultural Policy (1998-2010) was designed based on a vision of development of a dynamic agricultural sector focusing on an efficient market-led competitive growth. Provisions of necessary incentives and initiatives have been incorporated in the Third National Agricultural Policy plan to achieve the goal of maximizing income of the stakeholders through optimal utilization of resources.

To achieve the target of national plan and national agricultural policy, government has taken a large development project in the East Coast Economic Region (ECER) region. The ECER is more than half of the Peninsular Malaysia with an area of about 66,000sq $\mathrm{km}$ that covers the states Kelantan, Terengganu, Pahang and Mersing in Johor (Figure 1). The agricultural areas of Pahang, Terengganu and Kelantan are accounting for $34.8 \%$ of total agriculture areas in Malaysia. In 2004, Food crop production employing around 231,000 farmers in ECER. In 2005, the agriculture sector accounted for about $16 \%$ of the regional GDP and provided 22.9\% of the regional labor force (Malaysia 2006). 


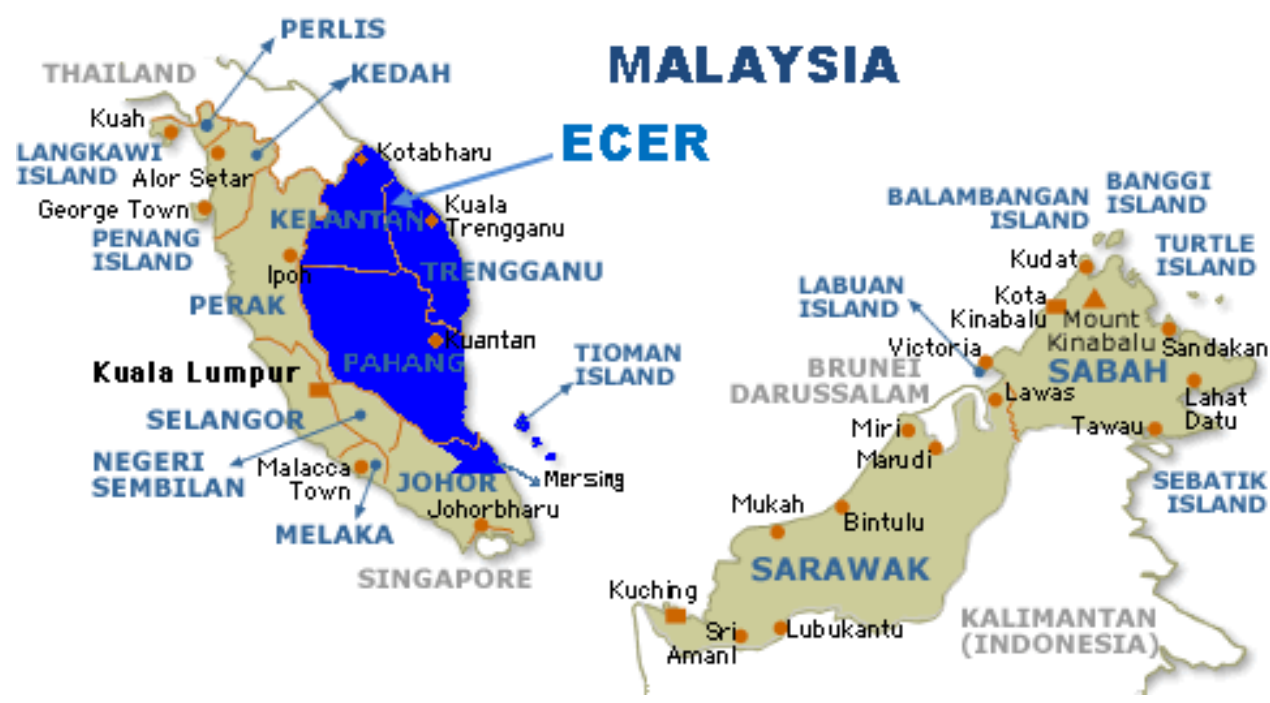

Figure 1: Location of ECER in Malaysian map

The ECER region is also very crucial for two major reasons -- (a) ECER is one of the important agricultural areas which has huge potentiality to improve the production, (b) due to the agro-based economy, the income level of this region is low and poverty rate is high that is a hinder to achieve vision 2020. The population of ECER was about 3.95 million, which represents $14.8 \%$ of the total population of Malaysia in 2005. The Gini coefficient for ECER was 0.46, Pahang 0.44, Terengganu 0.48 and Kelantan 0.45 in 2004. The household size for Kelantan is 5.2, Pahang is 4.2, and Terengganu is 5.0 persons, whereas for overall Malaysia the household size is 4.5 persons in 2004 . At that time, there were about 45,000 paddy farmers in the ECER, and the average productivity per worker was RM 11,915 whereas the national agriculture productivity per worker was RM 15,355. In 2004 the incidences of poverty were $10.6 \%, 4 \%$, and $15.4 \%$ in Kelantan, Pahang, and Terengganu respectively, whereas for overall Malaysia it was $5.7 \%$, and the incidences of hardcore poverty were $1.3 \%, 1.0 \%$, and $4.4 \%$ in Kelantan, Pahang, and Terengganu respectively, whereas for overall Malaysia it was $1.2 \%$. For the development of ECER region, in 2008 government has officially launched a very large development project, named "ECER Project", which will be the blueprint to guide the development in the region till 2020. ECER is expected to implement projects worth an estimated RM 112 billion in value by year 2020 . The ECER Special Economic Zone (SEZ) is expected to generate up to RM 90 billion in investments and contribute RM 23 billion to the national GDP, as well as create 220,000 new jobs out of the 560,000 jobs identified. But after taking the initiative, till now, there is a very limited number of studies conducted in this area, and the evaluation of the project is very limited. So, this study is an effort to explore the current initiatives, challenges and prospects, which are vital to achieve the target of the crop agricultural areas in ECER development project.

\section{Agricultural Crop Production in ECER}

Crop activity in the ECER is either industrial such as oil palm, rubber, tobacco and flowers, or food crops. In 2004, all crops production covered a total area of 2.22 million ha in the ECER (34.8\% of Peninsular Malaysia), where oil palm and rubber covered an area of 1.92 million ha (Table 1). The industrial crops accounted for $87 \%$ or 1.89 million ha of the total agricultural area in this region that consists of 1,375,682 ha oil palm, 501,281 ha rubber, 14,377 ha tobacco, and 220 ha flowers. Within the crop agricultural area, paddy, fruits and 
vegetables were cultivated in $5.4 \%, 4.66 \%, 0.62 \%$ of total ECER agricultural land area respectively (Table 1$)$.

Table 1: Agricultural Land Area (hectares) in the ECER States in 2004

\begin{tabular}{|c|c|c|c|c|c|}
\hline Crops & Kelantan & Terengganu & Pahang & $\begin{array}{l}\text { Mersing } \\
\text { District }\end{array}$ & Total \\
\hline Rubber & 151,878 & 73,619 & 275,784 & 2,296 & 503,577 \\
\hline Oil Palm & 76,407 & 169,059 & $1,130,216$ & 45,567 & $1,421,249$ \\
\hline Paddy & 71,134 & 29,617 & 17,388 & 1,214 & 119,353 \\
\hline Fruits & 56,175 & 23,523 & 21,300 & 2,656 & 103,654 \\
\hline Vegetables & 4,732 & 1,797 & 7,020 & 415 & 13,964 \\
\hline Coconut & 8,473 & 6,985 & 7,000 & 1,223 & 23,681 \\
\hline Tobacco & 11,479 & 2,883 & 15 & - & 14,377 \\
\hline Roselle & 20 & 100 & 40 & 50 & 240 \\
\hline Floriculture & 20 & - & 200 & - & 220 \\
\hline Others & 178 & 442 & 21,037 & 193 & 21,820 \\
\hline Total & 380,496 & 308,025 & $1,480,000$ & 53,614 & $2,222,135$ \\
\hline
\end{tabular}

Sources: Kelantan State Structure Plans 2003; Terengganu State Structure Plans 2005; Pahang State Structure Plans 2002; MoA 2004

Out of eight granary areas in Malaysia, three granary areas are situated in this region. In 2005, total 451,715 ha land area were used for paddy production in Malaysia in which 95,840 ha (or 21\%) were in the ECER. In Malaysia, approximately 245,000 ha land area were designated as granary and mini-granary areas, whereas 54,054 ha (or 22\%) of those areas were in the ECER (Table 2). In case of national paddy production, the granary areas contributed 1,530,000 metric tons, of which 243,878 metric tons (15.9\%) were from the ECER.

Table 2: Granary and Mini-Granary Land Areas (hectares) in the ECER in 2005

\begin{tabular}{llrrr}
\hline \multirow{2}{*}{ States } & \multirow{2}{*}{ Location } & \multicolumn{2}{c}{ Irrigated areas (ha) } & \multirow{2}{*}{ Total (ha) } \\
\cline { 3 - 4 } & & Granary & Mini-Granary & \\
\hline \multirow{2}{*}{ Kelantan } & KADA & 30,240 & - & 30,240 \\
\multirow{2}{*}{ Terengganu } & Kemasin-Semerak & 6,965 & 2,341 & 9,306 \\
\multirow{2}{*}{ Pahang } & KETARA (Besut) & 10,987 & - & 10,987 \\
& Pekan & & 647 & 647 \\
\hline Total & Rompin & - & 2,874 & 2,874 \\
\hline
\end{tabular}

Source: MoA 2005

Paddy yields in the ECER are lower than the western region of Peninsular Malaysia (Table 3). Many programs have been undertaken by the relevant authorities in the region, but paddy yields and productivity did not improve significantly over the years (ECER Master Plan 2007). The main reasons of poor yield are the less fertile soils in the ECER, inadequate irrigation facilities, and poor management. To improve rice productivity, there is a need to improve efficiency in in-field water management for three granary areas, which is expected to cost RM 561.6 million (Table 4). 
Table 3: Average Paddy Yield (Tones/Ha) in Different Granary Areas in Malaysia

\begin{tabular}{llrrrrr}
\hline Region & \multicolumn{1}{c}{ Granary Area } & 2000 & 2002 & 2003 & 2004 & 2005 \\
\hline \multirow{5}{*}{ ECER } & KADA & 3.45 & 2.58 & 3.25 & 3.63 & 3.16 \\
& Kemasin-Semerak & 3.61 & 1.47 & 2.9 & 2.97 & 2.45 \\
& KETARA (Besut) & 3.97 & 3.8 & 3.92 & 4.22 & 3.98 \\
& Pekan/Rompin & & & & & 2.96 \\
\hline \multirow{5}{*}{ Western } & MADA & 3.95 & 4.26 & 4.4 & 4.37 & 4.34 \\
Region & BL Selangor & 4.68 & 4.76 & 5.38 & 4.83 & 4.99 \\
& Pulau Pinang & 3.98 & 4.6 & 4.14 & 4.13 & 4.29 \\
& Seberang Perak & 3.88 & 4.46 & 3.82 & 3.44 & 3.91 \\
& Kerian/Sg.Manik & 2.58 & 3.07 & 3.12 & 2.89 & 3.03 \\
\hline
\end{tabular}

Source: MoA 2005, ECER Master Plan 2007

Table 4: Expected Cost (thousand RM) for Infrastructural Improvement in Granary Areas in ECER

\begin{tabular}{lrrrr}
\hline \multirow{2}{*}{ Granary Area } & \multicolumn{3}{c}{ Infrastructure Areas } & Total \\
& Irrigation & Drainage & Farm Roads & $\begin{array}{r}\text { Infrastructure } \\
\text { Cost }\end{array}$ \\
\cline { 2 - 4 } KADA & 319,914 & 37,030 & 78,288 & 435,141 \\
KETARA & 20,914 & 4,131 & 5,846 & 30,891 \\
Kemasin-Semerak & 69,502 & 9,184 & 16,769 & 95,454 \\
\hline Total & 410,330 & 50,344 & 100,903 & 561,577 \\
\hline
\end{tabular}

Source: Irrigation Division 2005

Competition for land also tends to affect total paddy cultivation in ECER. For example, in Kelantan State, land under paddy cultivation is expected to shrink from 37,515 ha in 2000 to 30,000 ha in 2020, at a reduction rate of $1 \%$ annually (Kelantan State Structural Plan 2003). Due to the lower cropping intensity, and small farm size in the ECER, productivity of paddy is low and income of paddy farming is also unattractive. With an average income of RM 1,200 per season or around RM 192 per month in 2005, the incidence of poverty among rice farmers is high. Paddy production in Malaysia is supported by input and price subsidies and cash incentives, totaling about RM 550 million in 2000 and RM 2.044 billion in 2007. To boost productivity and increase self-sufficiency level, government has been increasing and also adding new types of subsidy. The subsidies for urea and compound fertilizer have been continuing since 1979. The incentive for land preparation and using organic fertilizer has been continuing since 2007. Providing compound and urea fertilizers and pesticide incentives was introduced in 2008 and is still continuing (Alam et al. 2012).

The ECER has played an important role in the development of the fruit and vegetable industry in the country. It was counting as $41.22 \%$ of total Malaysian agricultural area in 2001. The value and area of fruit and vegetable production in ECER were estimated together at RM 1,664 million and 117,618 ha in 2005 (Table 5). The total production of vegetables in the Peninsula in 2005 was estimated at 683,427 metric tons, and ECER contributed $40 \%$ of it. The land area for fruits and vegetable agriculture was $41.22 \%$ (or 2.7 million ha) in 2001, but it is expected to increase to $52.39 \%$ (or 3.5 million ha) by 2020 (Malaysia 2006).

Table 5: Production Targets and Current Status of Crop Agriculture in the ECER 


\begin{tabular}{llrr}
\hline $\begin{array}{l}\text { Area, Volume and Value of } \\
\text { Crop Production }\end{array}$ & Crop Type & $\mathbf{2 0 0 5}$ & $\mathbf{2 0 2 0}$ \\
\hline & Fruits & 103,654 & 123,654 \\
Production area (ha) & Vegetables & 13,964 & 20,000 \\
& Paddy & 54,054 & 46,539 \\
\hline Volume of Production & Fruits & 518,270 & $1,236,540$ \\
(metric tons) & Vegetables & 104,730 & 600,000 \\
& Paddy & 243,878 & 418,851 \\
\hline Value of Production & Fruits and Vegetable & 1,664 & 2,664 \\
(RM million) & Paddy & 158,521 & 272,253 \\
\hline
\end{tabular}

Source: ECER Master Plan 2007

\section{ECER Master Plan}

The main objective of the ECER Master Plan is to achieve a viable, equitable and sustainable growth in the region. It emphasizes on the socio-economic growth of the population, equitable distribution of income, poverty reduction, employment generation, raising income level, and sustainable development through several programmers and projects in the region. The East Coast Economic Region Development Council (ECERDC) is responsible for the development of this region through policies, strategies, and coordination between government entities in the promotion of trade, investment, tourism and development activities within the region. The ECERDC is a statutory body established under the East Coast Economic Region Development Council Act 2008 (Act 688).

The ECER Master Plan has identified five several clusters as key initiatives in generating economic growth in the region. (1) The tourism sector focuses on mainland coastal development, sustainable island tourism, eco-tourism, cultural \& heritage, cross border and agro-tourism, home stay programs and hallmark events. (2) The oil, gas and petrochemical sector emphasizes on downstream products and diversification towards ethylene-based and propylene-based production with operation integration between existing locations (Kertih, Chukai, and Gebeng). (3) The manufacturing sector focuses on the extension of the existing value chain for raw materials and feedstock, and a competitive environment for non-resource based industries, such as boat-building and repair, automotive assembly and distribution, handicraft and textile making, and heavy industries, etc. (4) The agriculture sector emphasizes on the improvement of production through farming integration, participation into new ventures, usage of new farming techniques, and building global network. (5) The education program focuses on marketing education, R\&D with industrial partnerships, and adequate supply of professional and skilled workforce to meet the needs for accelerated development, technological upgrading, and competitiveness.

Table 6: Key Targets of ECER Master plan

\begin{tabular}{lll}
\hline Key Indicators & 2005 & 2020 \\
\hline GDP Growth Rates & $5.70 \%$ & $7.20 \%$ \\
GDP (in 1987 prices) & RM 23,140 billion & RM 65,930 billion \\
GDP Per Capita & RM 5,860 & RM 13,510 \\
Household Income & RM 2,267 & RM 5,227 \\
Employment & 1.36 million & 1.92 million \\
No. of Projects \& Programs & - & 227 \\
\hline
\end{tabular}




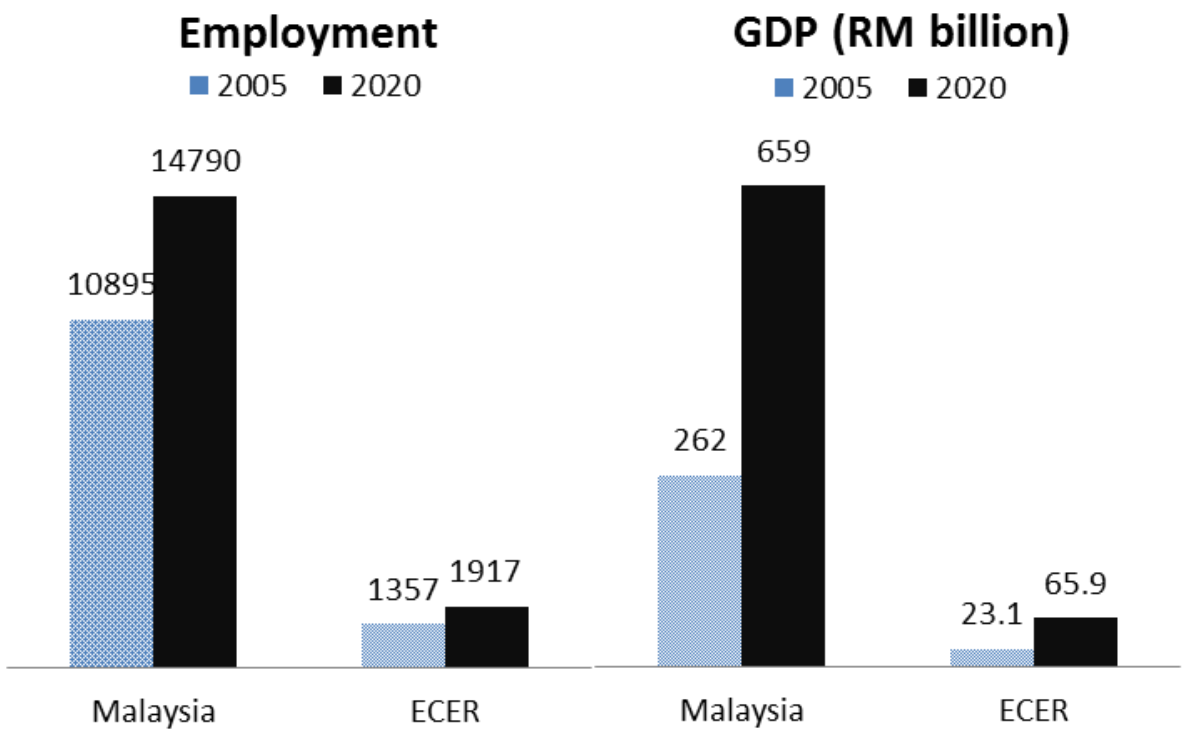

Figure 2: Employment and GDP in 2005 and 2020 Projection for Malaysia and ECER

Source: ECER Master Plan 2007

ECER master plan has setup several key targets for overall and individual sector. The project panned till 2020. It expects the GDP growth rate will increase to 7.2\%, and GDP per capita will be RM 13,510 (Table 6). It also expects to create 560,000 new job and 1.92 million total employments in this region. The growth of employment and GDP in ECER is expected to be more than that of overall Malaysia (Figure 2). To ensure this sort of growth rate, total 227 projects and programs will be implemented in this region by 2020 .

\section{Agricultural Plan}

One of the major economic thrusts of the ECER master plan is agricultural cluster that focuses on the development of crop-based farming, livestock (such as beef, mutton, poultry and animal feed) and fisheries. As agriculture is one of the main stream economic activities at the grass root level, improvement of this sector will play significant contributions to alleviate poverty and increase household incomes of the marginal groups in ECER.

The agricultural plans of ECER are based on several strategies where it focuses on the increases of agriculture production by venturing into large-scale commercial farming and using modern technology. The participation of private sector as anchor companies is expected to play a greater role in the development of agricultural sector as it will bring in entrepreneurial farmers and skilled workers to the industry. The plan also focuses on quality of production, crop management, pest, and disease control. Further, it focuses on a good supply chain and delivery system service that reduces post-harvest loss for agriculture, fisheries and livestock, and improves marketing channels. Through producing quality products, it is expected to reduce the reliance on agricultural imports and increase the export by achieving competitive production costs, which will improve the Balance of Trade (BOT). Moreover, agricultural programs also promote to increase non-farm opportunities, such as home-based manufacturing and production, where farmers can value-add their crops by doing 
simple processing, such as turning raw fruits to bottled juices or processed syrup. Another special program, named agropolitan, was introduced in the plan to attack hard-core poverty in a structured approach through higher-yield agricultural activities. Overall the agricultural programs focus on transforming traditional farming into modern and commercial entities to increase farmer's income, productivity and competitiveness.

\section{Crop Agricultural Plan}

Under the ECER crop agricultural development project several initiatives are already continuing to improve the production of paddy (Table 7), vegetables, and fruits. The attempt of this initiative is establishing three agro valleys as major vegetable and short-term crop growing areas involving organized modern farming methods in a sustainable manner to improve efficiency and productivity of agricultural production. Currently a vast area is used for short-term crop, such as watermelon, root vegetables, sweet corn, etc., cultivation where incidence of poverty is also high. The zone was identified as (a) 5,000 ha for the BachokBesut-Setiu-Kuala Berang agro valley in the districts of Bachok and Pasir Puteh in Kelantan and the districts of Besut, Setiu, Ulu Terengganu in Terengganu, (b) 1,000 ha for The Kuantan-Maran agro valley in the district of Kuantan Maran in Pahang and (c) 4,000 ha for the Pekan-Rompin-Mersing agro valley districts of Pekan, Rompin in Pahang, and Mersing in Johor. The area also includes marginal paddy areas in Kemasin-Semerak and tobacco areas for crop diversification. The implementation of the project is based on the contract farming with the basic necessary infrastructure such as roads, irrigation facilities drainage, and a number of supporting services including the establishment of collecting, processing and packaging centers (CPPC) in Besut, Kuantan and Rompin. Moreover, existing Permanent Food Production Parks in the Bachok-Besut-Setiu zone is also linked to the national food Terminal (TEMAN) that was established in Kota-Bharu in the Nine Malaysia Plan.

Table 7: Projection of Paddy Self Sufficiency Level in Malaysia

\begin{tabular}{cccccc}
\hline Years & $\begin{array}{c}\text { Total Paddy } \\
\text { Production } \\
\text { (thousand } \\
\text { metric tons) }\end{array}$ & $\begin{array}{c}\text { Milled Rice } \\
\text { equivalent } \\
\text { (thousand } \\
\text { metric tons) }\end{array}$ & $\begin{array}{c}\text { Total demand } \\
\text { of Rice } \\
\text { (thousand } \\
\text { metric tons) }\end{array}$ & $\begin{array}{c}\text { Production } \\
\text { shortfall or } \\
\text { Import } \\
\text { (thousand } \\
\text { metric tons) }\end{array}$ & $\begin{array}{c}\text { Self- } \\
\text { sufficiency } \\
\text { levels (\%) }\end{array}$ \\
\hline 2000 & 2141 & 1392 & 1962 & 594.1 & 66 \\
2005 & 2240 & 1456 & 2114 & 658 & 72 \\
2010 & 2343 & 1523 & 2300 & 777 & 66.2 \\
2015 & 2451 & 1593 & 2476 & 883 & 64.3 \\
2020 & 2564 & 1667 & 2628 & 961 & 63.4 \\
\hline
\end{tabular}

Source: ECER Master Plan 2007

Cameron Highlands is one of the major tea, vegetable and floriculture growing areas in Malaysia. In 2005, there were 2,036 ha under tea, 2,810 ha under vegetables and 379 ha under flowers. The annual production values were estimated at RM 135.8 million for vegetables and RM 193.6 million for flowers. Some of the vegetables and most of the flowers grown in this area are exported. Moreover, the establishment of a Permanent Vegetable and Floriculture Production Park (TKPM) in Lojing encourages the involvement of Bumiputera youth in highland agriculture and ensures sustainable development of the agricultural areas. An anchor company such as the Malaysian Agrifood Corporation (MAFC) under Khazanah National is involved to provide supply chain management. This project is an expansion of the existing scheme that has been implemented by the Kelantan DOA. This will cover an area of 
50 ha in Lojing of which only 10 ha is planted and improvement of 450 ha highland area of which only $30 \%$ of highland areas are cultivable.

The development of a citrus valley in Durian Mentangau in Dungun, Terengganu will cover the total area of 1414 ha of which about 500 ha have been developed by 8 companies and the remaining 964 ha is developing within the project period the area is gazetted as a 'Permanent Food Production Park' or TKPM under MOA jurisdiction for fruit cultivation with an emphasis on citrus. Under the TKPM modality, the MOA provides funds for basic infrastructure such as roads, irrigation and drainage, electricity and water as well as land clearing works. The Permanent Fruit Agricultural Park Project involves the development of 3,500 ha of land in Lanchang, Temerloh, for the development of commercial fruit orchards and 5,000 ha of state land in Ulu Tembeling, Jerantut, mostly for the new development of fruits orchards. Beside, around 400 ha land has been gazetted as Permanent Food Agricultural Park or TKPM to allow the participation of smallholders in fruit production.

For the cultivation of pineapple, 7,400 ha of state land in the district of Pekan and Rompin were taken under Pineapple Integrated Development Project. About 2,000 ha are planted with pineapple for the fresh fruit market and 5000 ha for varieties appropriate for canning. Under the project, about $70 \%$ of the land are developing by anchor companies, and the balance by smallholders under the out grower scheme. Each out grower is allocated a land area of 5-10 ha to be planted and supplied fresh fruits or process fruits. Overall the nucleus farm concept is adopted.

\section{Challenges of ECER Crop Agricultural Project}

The ECER development project is very wide in terms of objectives and geographical locations. As it is diversified in nature, to achieve the goals and targets the project is supposed to face several challenges. The activities and stakeholders of ECER master plan are not limited by the geographical locations, but the plan is prepared only for a specific area. Creation of the ECER development council means it is responsible to ensure effective implementation of the Master Plan, but to a large extent the implementation success depends on the commitment and cooperation among related states and stakeholders. The implementation approaches are also needed to be balanced with other regional development projects, such as Iskandar Development Region (IDR), Northern Corridor Economic Region (NCER), Sabah Development Corridor, and Sarawak Corridor of Renewable Energy (SCORE). Aligning the committed investment from public and private sector and its timely implementation are also two big challenges for the ECER development council.

The crop agricultural plan is a niche area of the overall plan, but it has significant linkages with several issues. Environment is one of the major issues for the sustainability of agriculture. Agricultural practices cause the degradation of the environment, such as soil erosion, salinity of rivers and groundwater contamination etc. Simultaneously, environmental factors also affect the agricultural outcomes, such as the adverse impacts of climatic changes. The agricultural sector in ECER is also vulnerable due to high variations in the climatic factors. The recent projection shows that maximum monthly precipitation will increase up to $51 \%$, and annual rainfall will increase up to $10 \%$ over Pahang, Kelantan and Terengganu (NAHRIM 2006). It is also projected that any change in rainfall, both positive and negative, by more than only $0.4 \%$ by 2020 will cause decline in yield of paddy production in Malaysia (NRS 2001). Alam et al. (2011) found that total yearly rainfall in Malaysia is increasing but its monthly variation is too high. In Malaysia, the effect of lower rainfall is almost possible to 
check through proper irrigation system, but the opposite phenomenon of over rainfall for any particular time, especially at the end of the crop cycle or at the maturity period, causes serious damages to the crops, which is absolutely uncontrollable for now. Still now, the agricultural sector is not able to meet its required water demand from all possible sources. However, it is expected that there will be shortage of water for agricultural production further due to more demand of water in other sectors. On the other hand, under current climate change scenario, temperature above $25^{\circ} \mathrm{C}$ may cause decline in grain mass by $4.4 \%$ (Tashiro and Wardlaw 1989 ) and in grain yield as much as 9.6-10.0\% per $1{ }^{\circ} \mathrm{C}$ rise in temperature (Baker and Allen 1993), whereas the average temperature in Malaysian rice growing areas is about $26^{\circ} \mathrm{C}$. In a recent study it has been found that a $1 \%$ increase in temperature will lead to a $3.44 \%$ decrease in current paddy yield and $0.03 \%$ decrease in paddy yield in next season, and at $1 \%$ increase in rainfall will lead to $0.12 \%$ decrease in current paddy yield and $0.21 \%$ decrease in paddy yield in next season (Alam et al. 2010).

Nowadays providing enough supports from institutions is also a big challenge. To ensure quality and variety of the planting materials, most of the required supports for fruit planting in case of group farming projects and Permanent Food Production Parks (TKPM) are sourced from the Department of Agriculture (DOA). But the capacity of the DOA to produce planting materials is limited, such as in 2006 DOA was able to supply only about $30 \%$ of the industry needs. The remaining was sourced from private nurseries, whose supply and quality are often not safeguarded by any accreditation scheme. Moreover, 90\% of the vegetables seeds are imported from abroad. Further, some of the mini-granaries and small-scale irrigation schemes in the ECER need to be upgraded to achieve targeted self-sufficiency level. Technological advancement is also essential to increase rice yields from 3.2 tons/ha to more than 6 tons/ha, and to increase cropping intensity from the present average of $160 \%$ to $185 \%$. Only providing better seeds, appropriate levels of fertilizer, better water management and other technology, such as precision farming, can ensure the target. A large investment and institutional arrangement are also needed for the required infrastructural development in the granary areas (Table 4). Supporting for the development of large-scale farming through group farming and an estate type production system also demand more institutional capacity.

A quick transportation system, especially for fruits and vegetables, is essential for cost reduction and maintaining quality. Without rapid transportation facilities, distributional cost increases for transportations and long term preservation. Since cost control is important for the economic sustainability of fruit and vegetable cluster, without good infrastructure and communication facilities many companies are not willing to locate their processing operations in the ECER, especially in Kelantan, Terengganu, and Mersing. So, new highways are essentially needed to link with various corridors, especially for the Central Corridor to maintain direct linkage with Port Klang and Singapore. At the same time, enough cold storage facilities are also needed in the area.

Marketing and distribution is always a challenge for agricultural product. Generally agricultural producers are small farmers, who have lack of information on crop statistics and pricing in different areas. Involvements of marketing intermediaries from farm collecting centers to packaging houses, and farms to retail outlets are resulting in lower prices for farmers. So, farmers' skills need to be developed to organize themselves into marketing cooperative or institutional involvement. This will also help to reduce the load of respected government institutions. 
Ensuring quality, market responsiveness, and innovations are also very important challenges for agro-product market. The customers expect better quality products. For example, Singaporeans demanding higher quality fruits and vegetables, at least the same level that is maintained by exporters from Australia, China, Taiwan, Indonesia and the USA. But Malaysian producers were not able to respond to the changing demands of the Singapore market. As a consequence, the share of Malaysia's exports to Singapore has been declining from $41 \%$ in 1998 to $28 \%$ in 2004. So, to achieve the target of Balance of Trade, Malaysian agriculture industry needs to improve production practices including the use of Good Agricultural Practices (GAP), standardized grading system, and better packaging system.

\section{Conclusions and Recommendations}

The ECER crop agricultural project is an innovative and timely project for the betterment of the region and also for food security of the nation. Moreover, the prospects of the project are very much anticipative, because the size of domestic market has grown in recent years due to the increase in per capita consumption, higher population, increase in foreign workers, and visitors to the country. From 2000 to 2005, per capita consumption of fruits and vegetables increased from $27.3 \mathrm{~kg}$ to $36.2 \mathrm{~kg}$ and from $14.7 \mathrm{~kg}$ to $27.1 \mathrm{~kg}$, respectively. In 2006, $90 \%$ of the total fruits production in the country supplied to the domestic market, and major portion of vegetables produced in Cameron Highlands was also sold locally. Moreover, the local demand for fruits and vegetables are projected to grow at very fast rate. To meet local demand by 2020, fruit and vegetables productions need to be increased by 3 million tons and 2.07 million tons, respectively. At the same time, rice production also needs to increase to attain the target of $70 \%$ self-sufficiency level.

It is therefore recommended that some new initiatives are necessary to achieve the targets and to ensure the success of the project. But appropriate initiatives are very essential to avoid environment degradations and adverse effects of climatic changes. Emphasizing on more production should not lead to environmental degradation. To overcome the problem of water shortage some initiatives are already taken, such as construction of new dams or tidal barrage on the Besut River, improvement in drainage facilities in the granary areas, improvement in irrigation efficiency through precision farming projects, coordination among farmer water-user groups, and improving on-farm water management, etc. Now it is very important to finish these projects on time and improve the current status by proper monitoring and management. Hence development and implementation of the National Highland Development Policy are also essential to ensure the sustainability of development activities in the highlands. Farmers also need training and awareness program related to the adaptation to climatic changes. Finally, several steps beyond the project plan, such as overcoming the challenges and limitations mentioned earlier related to the transportation, marketing, innovation, quality control, cold storages and other preservation facilities, backward linkage for ensuring availability of seeds, fertilizers and other raw materials, farmer's cooperative or institutional involvement for marketing, financial supports and subsidies, and proper cooperation among agents and departments, etc., are also important for the overall growth and sustainability of the project.

\section{Acknowledgement}

We are thankful to Ministry of Science, Technology and Environment of the Government of Malaysia for generously funding the research, under the Research University Grants (UKMAP-PLW-04-2010 and LRGS-TD-2011-UPM-UKM-KM-04). 


\section{References}

Alam, M.M., B. Talib, C. Siwar and M.E. bin Toriman, 2010. The impacts of climate change on paddy production in Malaysia: Case of paddy farming in north west Selangor. Proceedings of the International Conference of the 4th International MalaysiaThailand Conference on South Asian Studies. Mar 25-26, National University of Malaysia, Malaysia.

Alam, M.M., M.E. bin Toriman, C. Siwar and B. Talib, 2011. Rainfall variation and changing pattern of agricultural cycle. Am. J. Environ. Sci., 7: 82-89. DOI: 10.3844/ajessp.2011.82.89

Alam, M.M., Siwar, C., Mohd Ekhwan, T., Molla, R.I., and Talib, B., 2012. Climate Change Induced Adaptation by Paddy Farmers in Malaysia, Mitigation and Adaptation for Global Change, 17(2): 173-186. DOI: 10.1007/s11027-011-9319-5

Arshad, F.M., Shamsudin, M.N., \& Saleh, R. 1999. Food Security in Malaysia, Presented at Seminar on International Trade and Food Security. Asian Productivity Organization, Tokyo, February.

Baker, J.T. and L.H. Allen, Jr. 1993. Contrasting crop species responses to $\mathrm{CO}_{2}$ and temperature: Rice, soybean and citrus. Vegetatio, 104: 239-260. (online) http://www.jstor.org/pss/20029749 (accessed on 18 July 2011)

ECER Master Plan. 2007. Economic Drives of the Region- Agriculture, East Coast Economic Region Development Council.

ECER Master Plan. 2008. Key Targets, East Coast Economic Region (ECER) Master Plan, East Coast Economic Region Development Council. (online) http://www.ecerdc.com/ecerdc/masterplan2.htm (accessed on 18 July 2011)

Irrigation Division. 2005. Division of Irrigation \& Agricultural Drainage, Ministry of Agriculture and Agro-based Industry, Kuala Lumpur, Malaysia.

Kelantan State Structure Plans. 2003. Town and Country Planning Department, National Land Use Information Division, Ministry of Housing and Local Government, Malaysia.

Malaysia. 2006. Ninth Malaysia Plan, 2006-2010, Economic Planning Unit, Prime Minister's Department, Putrajaya.

Malaysia. 2011. Tenth Malaysia Plan, 2011-2015, Economic Planning Unit, Prime Minister's Department, Putrajaya.

Ministry of Agriculture, 1992. Second National Agricultural Policy (1992-1997), Ministry of Agriculture, Putrajaya, Malaysia.

Ministry of Agriculture, 2000. Third National Agricultural Policy (1998-2010), Ministry of Agriculture, Putrajaya, Malaysia.

MoA, 2004. Agriculture Statistics, Ministry of Agricultural and Agro Based Industry, Malaysia.

MoA, 2005. Agriculture Statistics, Ministry of Agricultural and Agro Based Industry, Malaysia.

NAHRIM. 2006. Study of the impact of climate change on the hydrologic regime and water resources of peninsular Malaysia, National Hydraulic Research Institute of Malaysia (NAHRIM) and California Hydrologic Research Laboratory (CHRL), Malaysia. (online)

http://www.nahrim.gov.my/download/pksa/RegHCM_PM_Report_9_21_06_Ex\%20v 1.pdf (accessed on 18 July 2011)

NRS, 2001. National response strategies to climate change. Ministry Sci., Technol. Environ., Malaysia.

(online) 
http://gedung.nahrim.gov.my/wapi/mctweb.dll/getObject?MID=WATER\%20RESOU RCES\&Sn=2038 (accessed on 18 July 2011)

Pahang State Structure Plans. 2002. Town and Country Planning Department, National Land Use Information Division, Ministry of Housing and Local Government, Malaysia

Tashiro, T. and I.F. Wardlaw, 1989. A comparison of the effect of high temperature on grain development in wheat and rice. Annals of Botany 64: 59-65. (online) http://aob.oxfordjournals.org/content/64/1/59.abstract (accessed on 18 July 2011)

Terengganu State Structure Plans. 2005. Town and Country Planning Department, National Land Use Information Division, Ministry of Housing and Local Government, Malaysia 